\title{
INFLUENCE OF INITIAL DENSITY ON INVENTORY PARAMETERS OF UNTHINNED NORWAY SPRUCE STANDS
}

\author{
Juris KATREVICS, Latvian State Forest Research Institute Silava, Rigas 111, Salaspils, Latvia, juriskatrevics@inbox.lv \\ Rolands KAPOSTINS, Latvian State Forest Research Institute Silava, Rigas 111, Salaspils, Latvia, rolands.kapostins@ silava.lv \\ Karlis BICKOVSKIS, Latvian State Forest Research Institute Silava, Rigas 111, Salaspils, Latvia, karlis.bickovskis@ silava.lv \\ Aris JANSONS, Latvian State Forest Research Institute Silava, Rigas 111, Salaspils, Latvia, aris.jansons@ silava.lv (corresponding author)
}

Initial density to large extent determined the stand development thus is crucial to ensure efficient transfer of genetic gain in forestry. Lower density may reduce the stand establishment costs, but also impact the stem quality and standing volume. Very limited information exists about older sparse plantations, therefore aim of the study was to characterize the forest inventory parameters of lowdensity Norway spruce (Pice abies (L.) Karst.) stands. Data were collected in two planted, un-thinned, 47 year old, pure stands in central part of Latvia $\left(56^{\circ} \mathrm{N}, 25^{\circ} \mathrm{E}\right)$ with initial density 600 and 1600 trees ha ${ }^{-1}$, growing on fertile mineral soil. Even the sparsest stand $\left(600\right.$ trees $\left.\mathrm{ha}^{-1}\right)$ had standing volume that was not significantly different from the average in Norway spruce forests in similar conditions at the age of 80 years $\left(294 \pm 28.8\right.$ and $318 \pm 18.7 \mathrm{~m}^{3} \mathrm{ha}^{-1}$, respectively), based on National Forest Inventory data. Mean height (21-22 m) and length of branch-free part $(<1 \mathrm{~m})$ as well as diameter of the thickest branch in bottom $2 \mathrm{~m}$ of the stem $(<2 \mathrm{~cm})$ and proportion of trees with stem cracks (4\%) was not affected by initial stand density. Mean breast height diameter decreased and lengths of dry-branch section increased with increasing initial stand density. The proportion of browsed trees was smaller in sparser stand (23\% vs. 31\%). Notably lower initial density of planted stands than currently required (2000 trees ha $\left.{ }^{-1}\right)$ can be used while avoiding negative impact on forest inventory parameters.

Keywords: competition, growth, initial spacing, stem quality, target diameter

\section{INTRODUCTION}

Forest regeneration requires substantial effort and greatly affects the economic output from a certain area of forest land. Due to rising costs of this forest management activity, two opposite decision had become increasingly more common in recent decades: a) relying on natural regeneration, often delaying the first thinnings and thus losing out on radial growth of trees and stand (land expectation) value (Fahlvik, 2005); b) planting lower number of trees per ha with improved soils scarification and genetic value of the planting material (Dzerina at al., 2016). Efficient transfer of genetic gain into forestry can notably raise the value of the stands (Ahtikoski et al., 2018; Jansons, Gailis, 2011, Jansson et al., 2017). Also more homogenous stands with lower density (depending on management regime) have a better resistance against disturbance e.g. wind (Donis et al., 2018, Gardiner, Quine, 2000, McClain, 1994). Planted stands and increased intensity of the use of whole tree biomass does not present the threat to genetic diversity (Runggis et al., 2019) of forest ecosystem (Čakšs et al., 2018; Lībiete et al., 2017), but rather substantial gain for carbon sequestration (K,ēnina et al., 2018). Also planted stands with good management have additional height increment at young age (Katrevics et al., 2018). Models, also ones including the genetic improvement component (Egbäck et al., 2017) can be used to predict the development of stands with different densities. However, the models are as good as the input data used for their development. Therefore empirical information from spacing (or precommercial thinning) trails is essential to test and fine-tune the models. Usually such trials include set of rather large densities (e.g. 3330-6660 trees ha ${ }^{-1}$, Mangalis, 1960) or analyse the stands at rather young age e.g. spruces at the age of 24-33 years (Deans, Milne, 1999, Pfister et al., 2007), lodgepole pine at 23 years (Liziniewicz et al., 2011), jack pine at 25 years (Hébert et al., 2016). Analysis of a single 40-year-old low-density (400 trees ha ${ }^{-1}$ ) plantation of silver birch clones growing on former agricultural land in the central Latvia was carried out. It was found, that trees had reached the target diameter for final harvest $(27.7 \pm 5.5 \mathrm{~cm})$ and stemood productivity was $5.25 \mathrm{~m}^{3} \mathrm{ha}^{-1} \mathrm{year}^{-}$

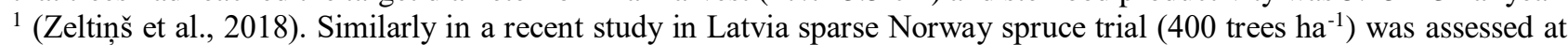
the age of 50 years and data compared to National Forest Inventory (NFI) plots (Katrevičs et el., 2018). The results suggest a high productivity of such stand and notable impact of clone (genetics). Mäkinen et al. (2000) in a detailed study involving a limited number of Norway spruce trees have found, that increasing stand density (350 to 1600 trees ha $^{-1}$ ) results in decrease in radial increment, but it had no effect on height increment. Closer spacing produces higher standing basal area and volume than wider spacing, especially at young age (Gizachew et al., 2012). To improve the overall understanding of initial spacing on stand development, aim of the study was to characterize the forest inventory parameters of low-density Norway spruce stands. Results can be further used in the development of forest management recommendations.

Copyright (C) 2019 The Authors. Published by Vytautas Magnus University. This is an open-access article distributed under the terms of the Creative Commons Attribution License (CC BY 4.0), which permits unrestricted use, distribution, and reproduction in any medium, provided the original author and source are credited. 


\section{MATERIALS AND METHODS}

Material was collected in two 47 year old, pure Norway spruce stands in central part of Latvia $\left(56^{\circ} \mathrm{N}, 25^{\circ} \mathrm{E}\right)$. According to data of Latvian Environment, Geology and Meteorology Centre, the climate is maritime, mild, 30-years mean air temperature in July and January is 18 and $-6{ }^{\circ} \mathrm{C}$, respectively. Annual sum of precipitation varies between 700 and $800 \mathrm{~mm}$. Soil was prepared in rows and stands were established by planting, with initial density 600 and 1600 trees ha${ }^{1}$. No thinning had been done before the measurements. Measurements were carried out in rectangular plots within the stand of size 0.35-0.4 ha, trees in outer border rows of the stands were no measured to avoid edge effect. Stands were located on fertile mineral soil with normal moisture regime, Oxalidosa forest type, where highest productivity of Norway spruce can be observed.

Algometric parameters of trees measured included height $(\mathrm{H}, \pm 0.1 \mathrm{~m})$, breast height $(1.3 \mathrm{~m})$ diameter (DBH, $\pm 0.1 \mathrm{~cm}$ ), height to the forest living branch, not separated from the next living branches by more than one branch whorl (crown base, $\pm 0.1 \mathrm{~m}$ ), diameter of the thickest branch in bottom $2 \mathrm{~m}$ of the stem $(\mathrm{mm})$, browsing damages: lowest and highest point of the scar $(\mathrm{cm})$ and length of the stem cracks. Additionally, occurrence of the dry trees (results of selfthinning) was recorded. Stem volume was calculated based on Liepa (1996). Significance of differences was tested by ANOVA, 95\% confidence interval was used show the variation throughout the manuscript. Data from low density stand, presented by Katrevičs at al. (2018) was used for comparison. Similarly, data from pure (at least $80 \%$ of the standing volume) Norway spruce stands on fertile mineral soil with normal moisture regime - altogether 31 plot with size 400 to $500 \mathrm{~m}^{2}$ - were used. Source of these data was National forest inventory (NFI) dataset. In these stands initial density is not known, rather assumed as it was in accordance to normative at that time (4000-7000 trees ha $\left.{ }^{-1}\right)$ and management history is not known.

\section{RESULTS AND DISCUSSION}

Survival had been better in stand with lower density $\left(600\right.$ trees $\left.^{-1} \mathrm{a}^{-1}\right)$, than in the stand with higher $(1600$ trees ha ${ }^{1}$ ), indicating notable effect of self-thinning. Even so, there were almost two-fold difference between the stands in the actual density at the time of the measurement: 451 and 883 trees ha $^{-1}$, respectively. Also the stands in traditional forest management, that were rather dense initially $\left(4000-7000\right.$ trees ha $\left.^{-1}\right)$, currently had the density of 526 trees ha ${ }^{-1}$ on average, as shown by National forest inventory (NFI) data.

Standing volume in sands with low initial density (400-600 trees ha ${ }^{-1}$ ) was slightly (on average by $47 \mathrm{~m}^{3}$ ), but statistically significantly larger than that in the Norway spruce stands with notably larger initial density (and un-known management history), represented in dataset of National forest inventory (Figure 1). It was not different than the average standing volume in Norway spruce stands approximately 30 years later - at the cutting age in accordance to the current legislation in Latvia $\left(318 \pm 18.7 \mathrm{~m}^{3} \mathrm{ha}^{-1}\right)$. However, it was significantly lower than that in the stand with initial density 1600 trees $\mathrm{ha}^{-1}$, indicating, that the biomass production had not been maximized in low-density stands. Similar results were found in young Pinus contorta stands in southern Sweden, where yield of low density (625 trees ha-1) plantations was considerably lower than that of higher density (1250 trees ha-1): 35-40 and 59-92 $\mathrm{m}^{3} \mathrm{ha}^{-1}$, respectively, at the age of 23 years (Liziniewicz et al., 2011). Based on the chronosequence approach, Zālitis et al. (2006) concluded, that early thinning (mean height of the stands 2-5 m) to density 1500-2000 trees ha-1 had resulted in notable increase of standing volume in stands at the age of 50 years: thus have found a similar trend, as in our study, when comparing the with the initial density 1600 trees $\mathrm{ha}^{-1}$ and NFI dataset.

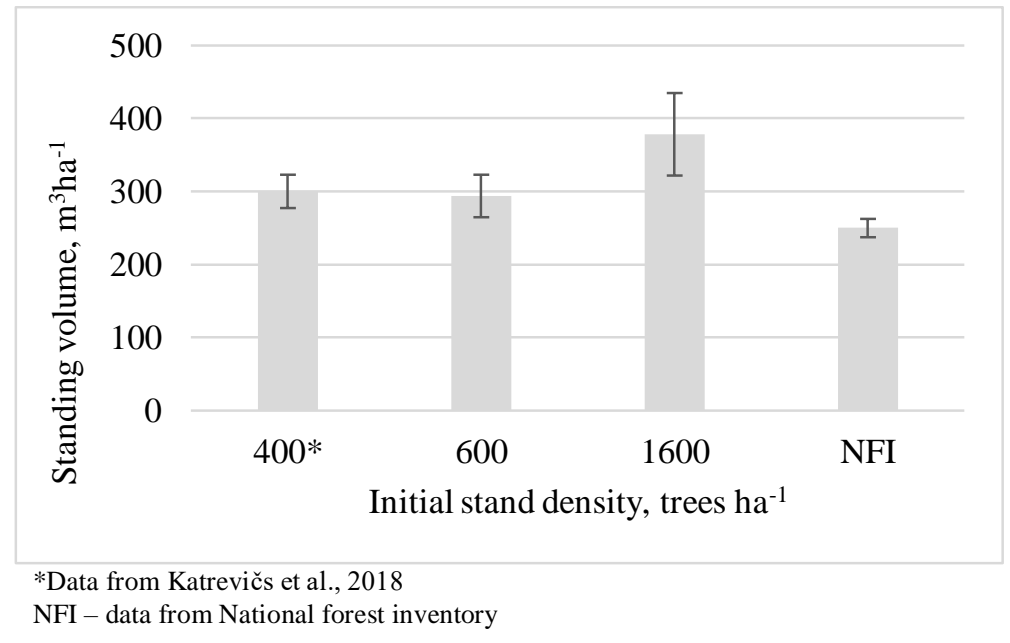

Figure 1. Standing volume in Norway spruce stands with various initial density

Initial stand density had significant influence on average breast height diameter of the trees: in low density stand it was considerably - on average by almost one third or $7.1 \mathrm{~cm}$ - larger than on higher density $\left(1600\right.$ trees ha $\left.{ }^{-1}\right)$. Shape of 
diameter distribution in the denser stand suggests, that it is strongly influenced by competition and large portion of small dimension alive spruces are present (Figure 3). Therefore its mean diameter is even smaller than that in stands with traditional management and high initial density (Figure 2), where most likely several thinnings had been carried out in past. Selection of largest trees with density corresponding to that in low-density stand (denoted as "1600-s" in Figure 2) ensure a significantly higher diameter, but still not as high as in the sparse stand. Trend of increase in mean tree diameter as the stand density decreases, are similar as reported in other studies of younger stands: at the age of 24-33 years for spruces (Deans, Milne, 1999, Pfister et al., 2007) and at the age of 23 years in for lodgepole pine in southern Sweden (Liziniewicz et al., 2011). In plantations of Norway spruce with rather high initial density (3330-6660 trees ha-1) and unknown management regime, at the age of 45-51 years (density 1729-1835 trees ha ${ }^{-1}$ ) mean diameter (17.9-18.6 cm) was slightly lower than that in denser stand of our study (Mangalis, 1960). It indicates a strong influence of self-thinning.

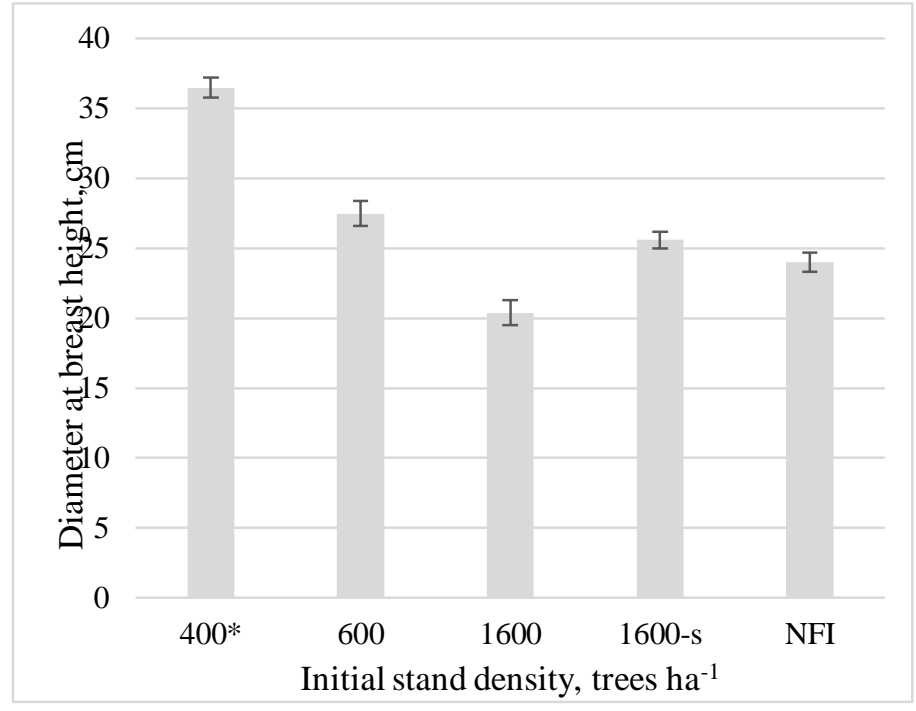

*Data from Katrevičs et al., 2018

NFI - data from National forest inventory

Figure 2. Diameter at breast height in Norway spruce stands with various initial density

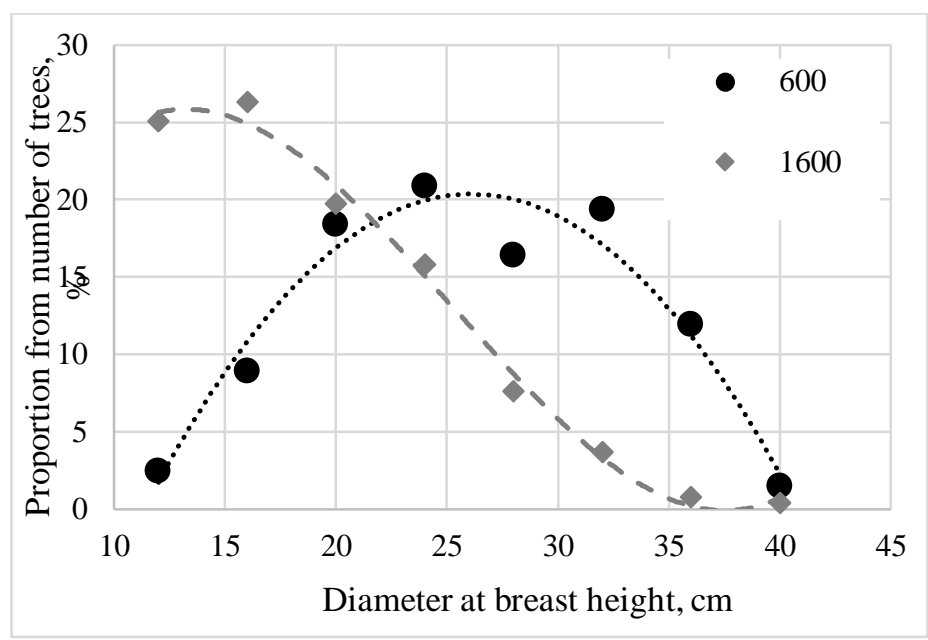

Trendlines included only for increased visibility of the differences between stands

Figure 3. Tree distribution in diameter at breast height classes in Norway spruce stands with various initial density

Tree height was not much affected by the difference in initial stand density (Table 1) as expected. It was slightly higher in stand in the same forest type and with even lower initial density (Katrevičs at al., 2018). This difference can be explained by tree breeding effect: notable genetic gains in height growth had been reported in the Baltic Sea region countries (Haapanen et al., 2016; Jansons et al., 2006, 2015; Jansson et al., 2017) and in the sparse Norway spruce stand in Latvia, that consisted of grafted first generation plus-trees (Katrevičs et al., 2018).

Height of first living branch was notably (by $4.2 \mathrm{~m}$ ) and significantly lower in stand with lower density, as was the crown ratio. Due to the larger space between the trees, also crown width was by one third larger, differences were statistically significant. It lead to shorter section of the trunk without green branches, however, that cannot be considered an improvement of stem quality - the dry-branch section was longer in the denser stand. It was because of the slow process of decay of the branches and healing over of the branch wound for Norway spruce (Baders et al., 2017). Very slow natural pruning was reported in studies of Norway spruce: branch-free part on average was only $0.3 \pm 0.07 \mathrm{~m}$ in 45 
stands at the age of 20 to 28 years (Baders at al., 2017) and 0.5 to $1 \mathrm{~m}$ in 10 stands at the age of 24 to 47 years (Mangalis, 1960). Thus, limited influence of stand density (if it is not very high) on natural pruning can be observed. It is consistent with the results of analysis of diameter of the thickest branch in bottom $2 \mathrm{~m}$ of the stem: no significant differences were found between the stands in our study and in both the diameter was below $2 \mathrm{~cm}$ (Table 1).

Table 1. Forest inventory parameters in Norway spruce stands with various initial density

\begin{tabular}{|l|l|l|l|}
\hline \multirow{2}{*}{ Tree parameters } & \multicolumn{3}{|c|}{ Initial stand density, trees ha $^{-1}$} \\
\cline { 2 - 4 } & \multicolumn{1}{|c|}{$400^{*}$} & \multicolumn{1}{|c|}{600} & \multicolumn{1}{c|}{1600} \\
\hline Tree height, $\mathrm{m}$ & $25.1 \pm 0.3$ & $22.2 \pm 0.4$ & $22.6 \pm 0.4$ \\
\hline Height of first living branch, $\mathrm{m}$ & $6.3 \pm 0.3$ & $7.9 \pm 0.3$ & $12.1 \pm 0.3$ \\
\hline Crown ration & $0.75 \pm 0.01$ & $0.66 \pm 0.01$ & $0.50 \pm 0.02$ \\
\hline Branch diameter, mm** & - & $15.4 \pm 4.0$ & $13.2 \pm 3.1$ \\
\hline Crown width, $\mathrm{m}$ & - & $2.4 \pm 0.1$ & $1.8 \pm 0.2$ \\
\hline Tree stem volume, $\mathrm{m}^{3}$ & $1.31 \pm 0.06$ & $0.65 \pm 0.04$ & $0.43 \pm 0.03$ \\
\hline
\end{tabular}

*Data from Katrevičs et al., 2018

**diamter of the thickest branch in bottom $2 \mathrm{~m}$ of the stem

Similarly, both stand did not differ in the mean length of browsing damages: it was $0.5 \pm 0.07 \mathrm{~m}$ in stand with density 600 trees ha ${ }^{-1}$, and $0.6 \pm 0.15 \mathrm{~m}$ in stand with density 1600 . The proportion of browsed trees was smaller in sparser stand (23\% vs. $31 \%$ ). Only few trees (4\%) had stem cracks wit length from 0.15 to $1.5 \mathrm{~m}$ (average $0.6 \pm 0.1 \mathrm{~m}$ ) in both stands. The study by Zeltiņš et al. (2018) found slight tendency of larger trees being more prone to cracks and much larger portion of trees with stem cracks $(23.5 \%)$ in a 35-year-old provenance trial. The differences in proportion of affected trees between the studies are most likely explained by the cause of stem cracks - prolonged severe drought event (Persson, 1994) - that evidently has not occurred in location of our stands.

\section{CONCLUSIONS}

Standing volume of untinned Norway spruce stands with low initial density (400-600 trees ha ${ }^{-1}$ ) was significantly (on average by $47 \mathrm{~m}^{3}$ ) larger than that in similar stands with notably larger initial density and traditional management regime, represented in dataset of National forest inventory $\left(297 \pm 25.7\right.$ and $250 \pm 12.5 \mathrm{~m}^{3} \mathrm{ha}^{-1}$, respectively); it was even higher in un-thinned stand with density 1600 trees ha $\mathrm{h}^{-1}: 378 \pm 56.7 \mathrm{~m}^{3} \mathrm{ha}^{-1}$. Height was unaffected by initial stand density, but mean breast height diameter decreased with increasing initial stand density. Largest trees (total stem volume $282 \mathrm{~m}^{3} \mathrm{ha}^{-}$ ${ }^{1}$ ) in stand with density 1600 trees $\mathrm{ha}^{-1}$ had only slightly, but significantly smaller DBH than the mean in sparse stands: $25.6 \pm 0.6$ and $27.5 \pm 0.9 \mathrm{~cm}$, respectively. Stand density had no significant impact on presence browsing damages and stem cracks as well as on diameter of the thickest branch in bottom $2 \mathrm{~m}$ of the stem. Results suggest, that the initial density lower than currently practiced could boost the diameter growth and thus reduce the time, when target diameter is reached. The optimum density presumably is above 600 trees ha $^{-1}$, to have larger standing volume, but below 1600 trees ha $^{-1}$, to ensure diameter growth, or this density with one thinning.

ACKNOWLEDGEMENT. Study was funded by Forest Competence Centre (ERDF) project "Technologies for efficient transfer of genetic gain in plant production and forestry" (No 1.2.1.1./18/A/004)

\section{REFERENCES}

1. Ahtikoski A., Haapanen M., Hynynen J., Karhu J., Kärkkäinen K. 2018. Genetically improved reforestation stock provides simultaneous benefits for growers and a sawmill, a case study in Finland. Scandinavian Journal of Forest Research, Vol. 33 (5), pp. 484-492. https://doi.org/10.1080/02827581.2018.1433229

2. Baders E., Donis J., Snepsts G., Adamovics A., Jansons,A. 2017. Pruning effect on Norway spruce (Picea abies (L.) Karst.) growth and quality. Forestry Studies, Vol. 66, pp. 33-48. https://doi.org/10.1515/fsmu-2017-0005

3. Čakšs R., Robalte L., Desaine I., Džeriņa B., Jansons A. 2018. Ground vegetation composition and diversity in drained Norway spruce (Picea abies (L.) Karst.) stands 50 years after whole-tree harvesting management: case study in Latvia. Forestry Studies, Vol. 69, pp. 33-43. https://doi.org/10.2478/fsmu-2018-0010

4. Deans J.D., Milne R. 1999. Effects of respacing on young Sitka spruce crops. Forestry, Vol. 72(1), pp. $47-57$. https://doi.org/10.1093/forestry/72.1.47

5. Donis J., Kitenberga M., Snepsts G., Dubrovskis E., Jansons A. 2018. Factors affecting windstorm damage at the stand level in hemiboreal forests in Latvia: case study of 2005 winter storm. Silva Fennica Vol. 52, 4. https://doi.org/10.14214/sf.10009.

6. Dzerina B., Girdziusas S., Lazdina D., Lazdins A., Jansons J., Neimane U., Jansons Ā. 2016. Influence of spot mounding on height growth and tending of Norway spruce: case study in Latvia. Forestry Studie,s Vol. 65, pp. 24-33. https://doi.org/10.1515/fsmu$\underline{\text { 2016-0009 }}$

7. Egbäck S., Nilsson U., Nyström K., Högberg K.-A., Fahlvik N. 2017. Modelling early height growth in trials of genetically improved Norway spruce and Scots pine in southern Sweden. Silva Fennica, Vol. 51, no. 3 article id 5662. https://doi.org/10.14214/sf.5662. 
8. Fahlvik N. 2005. Aspects of precommercial thinning in heterogeneous forests in southern Sweden. Doctor's dissertation. ISSN 1652-6880, ISBN 91-576-6967-8.

9. Gardiner B.A., Quine, C.P. 2000. Management of forests to reduce the risk of abiotic damage - a review with particular reference to the effect of strong winds. Forest Ecology and Management, Vol. 135, pp. 261-277. https://doi.org/10.1016/S03781127(00)00285-1

10. Gizachew B., Brunner A., Øyen B.H. 2012. Stand responses to initial spacing in Norway spruce plantations in Norway. Scandinavian Journal of Forest Research, Vol. 27, pp. 637-648. https://doi.org/10.1080/02827581.2012.693191

11. Haapanen M., Hynynen J., Ruotsalainen,S., Siipilehto J., Kilpeläinen M.-L. 2016. Realised and projected gains in growth, quality and simulated yield of genetically improved Scots pine in southern Finland. European Journal of Forest Research, Vol. 135 (6), pp 997-1009. https://doi.org/10.1007/s10342-016-0989-0

12. Hébert F., Krause C., Plourde P.Y., Achim A., Prégent G., Ménétrier J. 2016. Effect of trees spacing on tree level volume growth, morphology, and wood properties in a 25-years-old Pinus banksiana plantation in the boreal forest of Quebec. Forests, Vol. 7, id 276. https://doi.org/10.3390/f7110276

13. Jansons A., Donis J., Danusevičius D., Baumanis I. 2015. Differential analysis for next breeding cycle for Norway spruce in Latvia. Baltic Forestry, Vol. 21(2), pp. 285-297.

14. Jansons Ā., Gailis A., Donis J. 2011. Profitability of silver birch (Betula pendula Roth.) breeding in Latvia. In: Z. Gaile (ed.) Proceedings of the $17^{\text {th }}$ international scientific conference Research for Rural Development 2011, May 18-20, LLU, Jelgava, Latvia, pp. 33.-38.

15. Jansons Ā., Baumanis I., Dreimanis A., Gailis A. 2006. Variability and genetic determination of Scots pine quantitative traits at the age of 32 years. In: Z. Gaile (ed.) Proceeding of international scientific conference Research for Rural Development 2006, LLU, 17-20 of May, Jelgava, Latvia, pp. 289-295.

16. Jansson G., Hansen J.K., Haapanen M., Kvaalen,H., Steffenrem,A. 2017. The genetic and economic gains from forest tree breeding programmes in Scandinavia and Finland. Scandinavian Journal of Forest Research, Vol. 32(4), pp. $273-286$. https://doi.org/10.1080/02827581.2016.1242770

17. Katrevics J., Neimane U., Dzerina B., Kitenberga M., Jansons J., Jansons,A. 2018. Environmental factors affecting formation of lammas shoots in young stands of Norway spruce (Picea abies Karst.) in Latvia. iForest, Vol. 11, pp. 809-815. https://doi.org/10.3832/ifor2539-011

18. Katrevičs J., Džeriņa B., Neimane U., Desain, I., Bigača Z., Jansons Ā. 2018. Production and profitability of low density Norway spruce (Picea abies (L.) Karst.) plantation at 50 years of age: case study from eastern Latvia. Agronomy Research, Vol. 16, https://doi.org/10.15159/AR.18.014

19. Ķēniņa L., Elferts D., Bāders E., Jansons Ā. 2018. Carbon pools in a hemiboreal over-mature Norway spruce stands. Forests, Vol. 9(7), p. 435; doi: 10.3390/f9070435. https://doi.org/10.3390/f9070435

20. Liepa I. 1996. Pieauguma mācība [Increment doctrine], Jelgava, LLU, 123 p. [In Latvian].

21. Liziniewicz,M., Ekö P.M., Agestam E. 2011. Effect of spacing on 23-year-old lodgepole pine (Pinus contorta Dougl. var. latifolia) in southern Sweden. Scandinavian Journal of Forest Research, Vol. 27(4), pp. 1-11. https://doi.org/10.1080/02827581.2011.639798

22. Lībiete Z., Matisons R., Rieksts-Riekstins J., Priedītis A., Jansons J., Smilga J., Done G., Jansons Ā. 2017. Aboveground biomass equations of 40 year old Norway spruce in Latvia. Baltic Forestry, Vol. 23(2), pp. 515-521.

23. Mäkinen H., Hein, S. 2000. Effect of wide spacing on increment and branch properties of young Norway spruce. Eururopean Journal of Forest Research, Vol. 125, pp. 239-248. https://doi.org/10.1007/s10342-006-0115-9

24. Mangalis I. 1960. Egḷu stādījumu ražỉba Latvijas PSR [Porductivity of plated spruce stands in Latvia], LLA raksti, 11, pp. 491-507 [In Latvian].

25. McClain K.M., Morris D.M., Hills S.C., Buss L.J. 1994. The effect of initial spacing on growth and crown development for planted northern conifers. Forestry Chronicle, Vol. 70, pp. 174-182. https://doi.org/10.5558/tfc70174-2

26. Persson A. 1994. Stem cracks in Norway spruce in southern Scandinavia: causes and consequences. Ann. For. Sci. Vol. 51, pp. 315-327. https://doi.org/10.1051/forest:19940310

27. Pfister O., Wallentin C., Nilsson U., Ekö P.M. 2007. Effects of wide spacing and thinning strategies on wood quality in Norway spruce (Picea abies) stands in southern Sweden. Scandinavian Journal of Forest Research, Vol. 22, pp. 333-343. https://doi.org/10.1080/02827580701504951

28. Ruņgis D., Lībiete Z., Korica A., Katrevičs J., Jansons Ā., Veinberga I., Jansons J. 2019. Genetic diversity and differentiation of even-aged Norway spruce stands in Latvia. Baltic Forestry, Vol. 25 (1), pp. 45-51.

29. Zālītis P., Lībiete Z., un Zālīitis T., 2006. Mērḳtiecīgi izveidoto kokaudžu augšanas gaita un strukturēšanās [Growth and structuring of goal-oriented stands]. Mežzinātne, 16, pp. 9-29 [In Latvian with English summary].

30. Zeltiņš P., Matisons R., Gailis A., Jansons J., Katrevičs J., Jansons Ā. 2018. Genetic parameters of growth traits and stem quality of silver birch in a low-density clonal plantation. Forests ,Vol. 9(2), 52. https://doi.org/10.3390/f9020052 